\title{
MANAGEMENT EDUCATION FOR CONSTRUCTION IN POLAND AND PORTUGAL
}

\author{
Kazimierz Cieszyński ${ }^{1}$, Andrzej Minasowicz ${ }^{2}$, Paul Olaf Nowak ${ }^{3}$, José Cardoso Teixeira ${ }^{4}$
}

\author{
1, ${ }^{2}$ Warsaw University of Technology, Armii Ludowej 16, 00-637 Warsaw, Poland \\ ${ }^{3}$ Polish British Construction Partnership, Sp. z o.o., Wspólna 41/24, 00-519 Warsaw, Poland \\ ${ }^{4}$ Universtiy of Minho, Campus de Azeurem, 4700-058 Guimarćes, Portugal

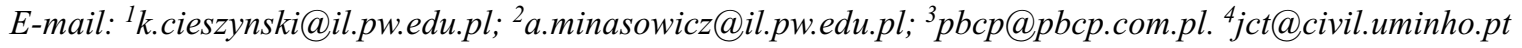

Received 25 May 2005; accepted 5 December 2005

\begin{abstract}
Countries emerging from centralised economies presently face the challenge of rapidly adapting their production structures to the market economy. In the last twelve years Poland has consistently evolved in that direction leading to the development of substantial construction investments and to the advent of thousands of small and medium construction companies. However, construction staff does not seem to fully stand for the demands of this shift, especially because of the lack of management skills now required. Portugal benefits from an uninterrupted process of development in a free economic market environment. Nevertheless, the broad nature of civil engineering undergraduate programmes does not allow young construction professionals to get these management skills at this level of studies. However, present requirements of project management expertise in the free European construction market call for the involvement of higher education institutions of both countries to answer industry demands in this field of knowledge. This paper reports the main objectives and findings of a survey conducted in the scope a Leonardo da Vinci project on the Polish education system requirements for technical and managerial skills of construction professionals.
\end{abstract}

Keywords: Management, learning, construction, Poland, Portugal.

\section{Introduction}

Management skills of construction staff are becoming a key requirement both for construction clients and contractor employers due to increasing complexity of construction projects and to present demanding market conditions of the construction activity. Although, for the same reasons, technical knowledge of construction professionals has successively gained in importance, it is now widely recognised that traditional engineering skills can no longer be dissociated from project management issues.

Civil engineering profession has long been design oriented by most Polish and Portuguese educational institutions, but current design engineering practice is increasingly conditioned by management options in many ways. Beyond cost and time planning and control, other management functions like quality, safety and environmental management now play an important role in the design phase of construction projects. Not only this asks for wider views of consulting engineers, but also demands for specific managerial skills at the design phase.

More significantly, insufficient preparation of construction management professionals seems to constitute a big problem both in Portuguese and Polish higher education institutions. Designed oriented curricula do not leave room for management topics in traditional civil engineering graduation profiles, this being a problem not adequately solved in either country so far. Professional experience of some years after graduation does not seem to overcome this drawback for most Portuguese and Polish civil engineers.

Therefore, the development of management skills has been increasingly sought by civil engineers currently working in consulting and construction organisations in both countries. The full integration of Portugal in the European Union and the integration of Poland in the near future raises new challenges to those professionals sharing their work environment with others possessing specific knowledge on management issues of the construction activity. 


\section{Background of the problem}

Both Portuguese and Polish engineering students in the construction field seek for the technical and managerial knowledge required to efficiently work in the European construction environment. Proportions of the needs for these two components are different in Poland, as a post-communistic country and in Portugal, as a free market country in the last decades [1].

Construction scientific and didactical qualification of two generations of Polish staff was moulded by political indoctrination and imposed by economic relations based on a centralised economical model that also embraced management of the construction activity in the country for fifty years. During this period the main duties of those involved in Polish construction projects was to carry out centrally planned investments at the pace of the financial supplies required. The job of construction staff was restricted to the execution of partial technical and administrative tasks. Independent investment initiatives were precluded and individuals were prevented to make decisions based on economical or organisational reasons that were specific to minister level only [1].

Half a century of such economical relations moulded the technical profile of civil engineers with a clear division: an elite of few working in state-owned design offices and a large set of construction managers supervising unqualified workers, army and even prisoners. In order to prevent scientific staff from interfering into politics and economy, the education model created for civil engineers was mainly directed to design subjects and to mathematical tools supporting design issues [1].

In the last twelve years, Polish economy has been transformed towards the free market model and construction investment market has consequently made its way. However, higher education for civil engineers is still directed to the design area, partially because tradition is kept on by university staff with long design lecturing background and some resistance to change. Moreover, under current Polish law system economical organisations have no influence in defining education profiles though they are now the main recipients of students graduated under those profiles [1].

Recently established thousands of small and medium construction enterprises feel many difficulties to integrate the rapidly evolving Polish construction market and do not find adequately prepared staff to fulfil interdisciplinary and independent economical functions.

Portugal benefits from an uninterrupted process of development in free economic market environment. Contrary to Polish, Portuguese young people enrolling the university are therefore clearly aware of market relations and have basic preparation to integrate the work force after graduation. This is acquired unconsciously through the influence of the environment (family, media, earlier education, etc.). However, this has not proved to be sufficient to perform management duties required by the construction industry in this country as well [2].

Presently, a number of Portuguese higher education institutions offer a five year undergraduate programme in civil engineering with substantial roots in two main engineering schools founded several decades ago. Those schools have long established a quite broad programme in civil engineering that subsequently became followed by the newer ones. Graduation traditionally covers a variety of areas such as structures, foundations, hydraulics, construction materials, construction technology, roads and town planning. Most courses are design oriented, but the number of management related courses is slowly increasing, partially reflecting industry claims for deeper skills of this field of knowledge. Those courses, along with a set of other most directed to the construction technology form the core of professional knowledge of young graduates starting a career in the construction industry [3].

Civil engineering has long been the most recognised technical degree for working in any construction related area in Portugal, including construction project management. The relative isolationism of this country during a great part of the last century, the small dimension of the national construction market, the short number of graduates and the good reputation of the profession kept on that tradition until the present days. Nevertheless, a broad nature of civil engineering undergraduate programme does not allow young professionals to get specialisation in that field at this level. Therefore, graduate programmes on management for civil engineers seem to better fit professional needs.

\section{Inquiries to Polish construction stakeholders}

\subsection{Inquiry to construction managers}

The aim of the inquiry was to find the opinion of respondents on the following subjects [3]:

- the qualification profiles required for construction engineering practice in Poland;

- the training programme to achieve these qualification profiles, including design methodology and lecturing staff.

In order to support the inquiry a questionnaire has been produced and mailed to a set of construction professionals graduated form technical Polish Universities. A total of 346 answers to the questionnaire has been collected according to the results presented in Table 1 .

\subsection{Inquiry to managers of the construction} cluster

A second inquiry has been conducted to a set of professionals performing different management tasks in Polish construction companies [3]. The aim of this inquiry was the 
Table 1. Qualification Profiles and Training Programme

\begin{tabular}{|c|c|c|c|}
\hline & \multirow{2}{*}{ Topic } & \multicolumn{2}{|c|}{ Answers } \\
\hline & & Topic & Answers \\
\hline 1 & $\begin{array}{l}\text { Qualification profiles and training programmes should allow students to } \\
\text { achieve: }\end{array}$ & & \\
\hline A & $\begin{array}{l}\text { Professional preparation to fulfil specific functions in economic units of } \\
\text { construction activity (students as the focus of the education process). }\end{array}$ & $89 \%$ & $11 \%$ \\
\hline $\mathrm{B}$ & $\begin{array}{l}\text { Theoretical knowledge lectured by staff aware of the latest scientific } \\
\text { achievements (students as the focus of the lecturing activity). }\end{array}$ & $48 \%$ & $52 \%$ \\
\hline 2 & $\begin{array}{l}\text { Taking into account current demand for engineers in the construction activity } \\
\text { and their qualification profiles, express your opinion on the following } \\
\text { sentences: }\end{array}$ & & \\
\hline A & $\begin{array}{l}\text { Graduation should provide theoretical and technical knowledge basically } \\
\text { directed for design of construction undertakings; engineers acquire } \\
\text { management skills they need in the course of their professional activity. }\end{array}$ & $32 \%$ & $68 \%$ \\
\hline $\mathrm{B}$ & $\begin{array}{l}\text { Graduation profiles should be in accordance to market needs; } \\
\text { complementary studies (e.g. MSc, PhD and other graduate studies) should } \\
\text { cater for specialisation profiles. }\end{array}$ & $90 \%$ & $10 \%$ \\
\hline 3 & $\begin{array}{l}\text { In market economy environment graduate programmes and qualification } \\
\text { profiles should be created }\end{array}$ & & \\
\hline A & Only by university staff. & $6 \%$ & $94 \%$ \\
\hline $\mathrm{B}$ & With significant participation of employers & $98 \%$ & $2 \%$ \\
\hline 4 & $\begin{array}{l}\text { What type of lecturing staff should be involved in a new degree in } \\
\text { Construction Engineering and Management (CEM)? }\end{array}$ & & \\
\hline A & $\begin{array}{l}\text { Basically, lecturers holding adequate scientific degrees in the subject areas } \\
\text { concerned }\end{array}$ & $6 \%$ & $94 \%$ \\
\hline $\mathrm{B}$ & $\begin{array}{l}\text { Lecturers with professional qualifications and successful careers in } \\
\text { construction, as well. }\end{array}$ & $98 \%$ & $2 \%$ \\
\hline 5 & $\begin{array}{l}\text { Assuming that both technical and management topics will be balanced in a } \\
\text { new CEM degree, which groups of technical subjects should loose } \\
\text { importance in favour of management topics? }\end{array}$ & & \\
\hline A & Subjects partially repeating earlier knowledge from high school. & $63 \%$ & $37 \%$ \\
\hline B & Computer aided design of structures. & $50 \%$ & $50 \%$ \\
\hline $\mathrm{C}$ & $\begin{array}{l}\text { General subjects often present in current engineering degrees not specifically } \\
\text { related to construction engineering }\end{array}$ & $42 \%$ & $58 \%$ \\
\hline $\mathrm{D}$ & Design of complicated engineering structures. & $57 \%$ & $43 \%$ \\
\hline
\end{tabular}

Table 1. Qualification Profiles and Training Programme (continuation)

\begin{tabular}{|c|c|c|c|c|c|}
\hline & Topic & $\begin{array}{c}\text { Very } \\
\text { important }\end{array}$ & $\begin{array}{c}\text { Impor- } \\
\text { tant }\end{array}$ & $\begin{array}{c}\text { Not } \\
\text { important }\end{array}$ & Useless \\
\hline 6 & $\begin{array}{l}\text { How important are the following groups of technical subjects for construction } \\
\text { practice? }\end{array}$ & & & & \\
\hline A & Subjects partially repeating earlier knowledge from high school. & $11 \%$ & $14 \%$ & $24 \%$ & $51 \%$ \\
\hline B & Computer aided design of structures. & $52 \%$ & $15 \%$ & $23 \%$ & $10 \%$ \\
\hline $\mathrm{C}$ & $\begin{array}{l}\text { General subjects often present in current engineering degrees not specifically } \\
\text { related to construction engineering }\end{array}$ & $11 \%$ & $48 \%$ & $30 \%$ & $11 \%$ \\
\hline $\mathrm{D}$ & Design of complicated engineering structures. & $27 \%$ & $32 \%$ & $25 \%$ & $16 \%$ \\
\hline 7 & $\begin{array}{l}\text { How important are the following qualification profiles for an engineer acting in } \\
\text { the Polish building market today? }\end{array}$ & & & & \\
\hline A & Building materials, pre-cast components and building products. & $8 \%$ & $29 \%$ & $29 \%$ & $34 \%$ \\
\hline B & Construction management and site direction & $32 \%$ & $27 \%$ & $36 \%$ & $5 \%$ \\
\hline $\mathrm{C}$ & Project management and project investment analysis & $74 \%$ & $19 \%$ & $2 \%$ & $5 \%$ \\
\hline $\mathrm{D}$ & Corporate management & $53 \%$ & $33 \%$ & $14 \%$ & $0 \%$ \\
\hline E & Real estate management. & $11 \%$ & $34 \%$ & $30 \%$ & $25 \%$ \\
\hline 8 & Which format for CEM degree? & & & & \\
\hline A & Undergraduate and graduate studies. & $33 \%$ & $28 \%$ & $13 \%$ & $26 \%$ \\
\hline B & Three year continuos professional development studies. & $8 \%$ & $22 \%$ & $35 \%$ & $35 \%$ \\
\hline C D & MSc for graduates in construction and building areas. & $38 \%$ & $43 \%$ & $19 \%$ & $0 \%$ \\
\hline \multirow[t]{2}{*}{$\mathrm{E}$} & Distance learning MSc for graduates in construction and building areas. & $17 \%$ & $33 \%$ & $19 \%$ & $31 \%$ \\
\hline & Postgraduate studies including a specialisation area. & $41 \%$ & $34 \%$ & $16 \%$ & $9 \%$ \\
\hline
\end{tabular}


Table 2. Inquiry results

\begin{tabular}{|c|c|}
\hline Number of years of practice & Percentage of answers, $\%$ \\
\hline Up to 5 & 10,5 \\
\hline From 6 to 10 & 5,3 \\
\hline From 11 to 15 & 5,3 \\
\hline More than 15 & 78,9 \\
\hline
\end{tabular}

characterisation of management demand for engineers. A total of 424 persons with a variety of graduation background participated in the inquiry. Most hold engineering graduation from Polish Technical Universities; some have nontechnical background, although they currently undertake management duties in construction company organisations. The experience of the respondents can be measured by the number of years of practice after graduation as depicted in Table 2.

In the first part of the inquiry respondents described their principal management duties and concerns.

Data recovered is listed in Table 3 below.

Most of the respondents stated that the level of their technical background studies was high, but complained

Table 3. Management and duties in construction

\begin{tabular}{|c|c|}
\hline $\begin{array}{l}\text { Management } \\
\text { professionals }\end{array}$ & Management duties and concerns \\
\hline Site managers & $\begin{array}{l}\text { Ordering of construction materials, } \\
\text { components and plant. } \\
\text { Construction planning and scheduling. } \\
\text { Cost planning and control. } \\
\text { Working with people with different } \\
\text { background }\end{array}$ \\
\hline $\begin{array}{l}\text { Production } \\
\text { managers }\end{array}$ & $\begin{array}{l}\text { Company organisation. } \\
\text { Team leadership. } \\
\text { Task planing at the organisation level. } \\
\text { Making business with other companies. }\end{array}$ \\
\hline $\begin{array}{l}\text { Procurement } \\
\text { professionals }\end{array}$ & $\begin{array}{l}\text { Dealing with people with different } \\
\text { backgrounds. } \\
\text { Administrative documents. }\end{array}$ \\
\hline Project managers & $\begin{array}{l}\text { Interacting with people with different } \\
\text { backgrounds. } \\
\text { Investment decision. } \\
\text { Dealing with administrative and economical } \\
\text { issues }\end{array}$ \\
\hline $\begin{array}{l}\text { Design team } \\
\text { leaders }\end{array}$ & $\begin{array}{l}\text { Making information available for the team } \\
\text { leaders. } \\
\text { Multidisciplinary design team leadership. } \\
\text { Dealing with distant projects. }\end{array}$ \\
\hline $\begin{array}{l}\text { Design company } \\
\text { managers }\end{array}$ & $\begin{array}{l}\text { Information flow and updating. } \\
\text { Staff management. } \\
\text { Project financing. }\end{array}$ \\
\hline $\begin{array}{l}\text { Marketing } \\
\text { professionals }\end{array}$ & $\begin{array}{l}\text { Work supervision. } \\
\text { Interacting with design offices. }\end{array}$ \\
\hline $\begin{array}{l}\text { Laboratory } \\
\text { technicians }\end{array}$ & Organising and training. \\
\hline Quality managers & $\begin{array}{l}\text { Activity co-ordination among project } \\
\text { participants. } \\
\text { Generating quality information. } \\
\text { Quality assurance. }\end{array}$ \\
\hline $\begin{array}{l}\text { Company } \\
\text { managers }\end{array}$ & $\begin{array}{l}\text { Organising and supervising work. } \\
\text { Tendering. }\end{array}$ \\
\hline
\end{tabular}

about too many theoretical subjects and limited time for practising on construction sites. Moreover, a significant number mentioned the lack of awareness of the investment process in construction and few time devoted to subjects in the management field in their undergraduate curricula. The level of their technical background is poor for $21 \%$ of the respondents, average for $47 \%$ and relevant for $32 \%$.

In the second part of the inquiry respondents analysed the set of essential subjects to be considered in construction project management studies. Results are reported in Table 4 below.

According to the results of the inquiry the development of both BSc and MSc seems adequate to fulfil Polish market demand. Undergraduate studies should also encompass construction technical knowledge whereas graduate studies are expected to have a narrower specialisation in construction management. Table 5 below summarises management subjects and their importance as identified by respondents [4].

In the third part of the inquiry, an opinion from respondents was sought on the improvement of current management practices in construction. Table 6 below summarises findings.

\section{A Portuguese experience}

The civil engineering department of the University of Minho, Portugal, launched in 1997 a graduate MSc programme on Construction and Real Estate Management.

Table 4. Essential subjects for project managers

\begin{tabular}{|c|c|c|}
\hline & Topic & $\begin{array}{c}\text { Ans- } \\
\text { wers, } \%\end{array}$ \\
\hline 1 & $\begin{array}{l}\text { Most important areas of company management } \\
\text { that should be lectured at graduation level: } \\
\text { company professional training policy; } \\
\text { management of human resources and } \\
\text { human capital investment; } \\
\text { staff of motivation policy. }\end{array}$ & $\begin{array}{l}92 \\
92 \\
88\end{array}$ \\
\hline 2 & $\begin{array}{l}\text { The qualification profiles of studies should be: } \\
\text { conformed to practical professional } \\
\text { preparation; } \\
\text { according to market demand. }\end{array}$ & $\begin{array}{l}89 \\
90\end{array}$ \\
\hline 3 & $\begin{array}{l}\text { Qualification profiles and programmes of studies } \\
\text { created by employers: } \\
\text { yes. }\end{array}$ & 98 \\
\hline 4 & $\begin{array}{l}\text { Professional qualification of staff confirmed by } \\
\text { experience and success in the industry. }\end{array}$ & 96 \\
\hline 5 & $\begin{array}{l}\text { Areas of managerial knowledge mostly required: } \\
\text { project management; } \\
\text { construction company management. }\end{array}$ & $\begin{array}{l}93 \\
86\end{array}$ \\
\hline 6 & $\begin{array}{l}\text { The most urgent types of studies: } \\
\text { MsC complementary studies on the } \\
\text { faculty of Construction Engineering } \\
\text { and Management for graduates on } \\
\text { construction related technical studies; } \\
\text { postgraduate studies with narrow } \\
\text { specialisation; } \\
\text { two degree studies (MSc and BSc). }\end{array}$ & $\begin{array}{l}75 \\
61 \\
\end{array}$ \\
\hline
\end{tabular}


Table 5. Priorities in construction management curricula

\begin{tabular}{|c|c|c|c|c|}
\hline & Topics & Yes, \% & No, $\%$ & $\begin{array}{l}\text { Not impor- } \\
\text { tant, \% }\end{array}$ \\
\hline 1 & Selected parts of mathematics, e.g., probability & 57 & 24 & 19 \\
\hline 2 & Operational research and mathematical optimisation tools & 62 & 14 & 24 \\
\hline 3 & Commercial law & 100 & 0 & 0 \\
\hline 4 & Investment project analysis & 100 & 0 & 0 \\
\hline 5 & Project management & 100 & 0 & 0 \\
\hline 6 & Starting and conducting of construction businesses & 87 & 0 & 13 \\
\hline 7 & Risk analysis in tendering and contracting arrangements & 92 & 0 & 8 \\
\hline 8 & Financing of construction activity & 84 & 8 & 8 \\
\hline 9 & System analysis & 90 & 5 & 5 \\
\hline 10 & Construction site management & 82 & 4 & 14 \\
\hline 11 & Production management & 68 & 4 & 28 \\
\hline 12 & Construction site planning & 75 & 0 & 25 \\
\hline 13 & Construction technology & 78 & 0 & 22 \\
\hline 14 & Industrial technology and organisation & 67 & 10 & 23 \\
\hline 15 & Resource management and site control & 90 & 5 & 5 \\
\hline 16 & Construction company management & 92 & 4 & 4 \\
\hline 17 & Computer aided planning & 82 & 14 & 4 \\
\hline 18 & Computer aided corporate management & 74 & 9 & 17 \\
\hline 19 & Computer aided design & 87 & 4 & 9 \\
\hline 20 & Cost estimation and tendering & 87 & 0 & 13 \\
\hline 21 & Economic efficiency of construction investments & 88 & 0 & 12 \\
\hline 22 & Marketing in construction industry & 83 & 4 & 13 \\
\hline 23 & Quality management systems for construction & 79 & 0 & 21 \\
\hline 24 & Environmental management in construction & 75 & 0 & 25 \\
\hline 25 & Building installations & 45 & 23 & 32 \\
\hline 26 & Facility management & 56 & 17 & 27 \\
\hline 27 & Building maintenance and refurbishment & 54 & 18 & 28 \\
\hline 28 & Building, conflict solving and motivation & 82 & 9 & 9 \\
\hline
\end{tabular}

Table 6. Improvement of current management practices

\begin{tabular}{|c|c|c|c|c|}
\hline & Topics & Yes, \% & No, $\%$ & $\begin{array}{c}\text { Not impor- } \\
\text { tant, } \%\end{array}$ \\
\hline 1 & Authority and responsibility of management staff and hierarchy relations & 74 & 22 & 4 \\
\hline 2 & Company organisation structure and functional relations & 71 & 29 & 0 \\
\hline 3 & Procedures for document producing and for information flow & 77 & 18 & 5 \\
\hline 4 & Activity planning for company operations and client needs & 75 & 20 & 5 \\
\hline 5 & Clear task definition for company operations & 67 & 25 & 8 \\
\hline 6 & Data collection and standards for task performance & 74 & 10 & 16 \\
\hline 7 & Motivation & 88 & 0 & 12 \\
\hline 8 & System monitoring and control & 70 & 22 & 8 \\
\hline 9 & Company training and promotion policies & 92 & 8 & 0 \\
\hline 10 & Quality standard and quality system definition at the company level & 83 & 13 & 4 \\
\hline 11 & Human resource management and qualification standards & 92 & 8 & 0 \\
\hline 12 & Resource management & 52 & 35 & 13 \\
\hline 13 & Information technologies & 65 & 26 & 9 \\
\hline 14 & Work environment quality & 68 & 24 & 8 \\
\hline 15 & Conflict solving and motivation & 78 & 9 & 13 \\
\hline 16 & Quality management systems & 78 & 11 & 11 \\
\hline
\end{tabular}


Table 7. MSc in Construction and Real-Estate Management

\begin{tabular}{|c|c|c|}
\hline Economic Sciences & Company Sciences & Legal Sciences \\
\hline $\begin{array}{l}\text { Economic and International Trading } \\
\text { Economy Module } \\
\text { Management Economics } \\
\text { Portuguese Economy } \\
\text { Industrial Economics }\end{array}$ & $\begin{array}{l}\text { Management Accounting } \\
\text { Company Finance Module } \\
\text { Company Finance I } \\
\text { Company Finance II } \\
\text { Company Sciences Module } \\
\text { Company Organisation and } \\
\text { Administration } \\
\text { Finance strategy in the long run } \\
\text { Marketing Module } \\
\text { Marketing I } \\
\text { Marketing II } \\
\text { Organisational behaviour and human } \\
\text { resources } \\
\text { Planning and control }\end{array}$ & $\begin{array}{l}\text { Fundamentals of Portuguese and } \\
\text { European Law } \\
\text { Company law } \\
\text { Contract law }\end{array}$ \\
\hline $\begin{array}{c}\text { Production Engineering and Systems } \\
\text { Engineering }\end{array}$ & Computer Engineering & Civil Engineering \\
\hline $\begin{array}{l}\text { Quantitative methods for decision support } \\
\text { Systems engineering module } \\
\text { Statistics } \\
\text { Fundamentals and developments of } \\
\text { industrial management } \\
\text { Project and operations management }\end{array}$ & Information systems & $\begin{array}{l}\text { Construction Management Module } \\
\text { Research methodology in construction } \\
\text { management } \\
\text { International construction } \\
\text { Management of MSM construction } \\
\text { companies } \\
\text { Production management, site } \\
\text { organisation and construction safety } \\
\text { Contract management and law in } \\
\text { construction and town planning } \\
\text { Project management in construction (I+II) } \\
\text { Construction technologies (I+II) } \\
\text { Real estate evaluation and management } \\
\text { Quality management in construction }\end{array}$ \\
\hline
\end{tabular}

This followed from the general perception of the lack of management background of construction professionals operating in Portuguese construction industry and from the number of civil engineers seeking for complementary management training in graduate learning programmes [5]. The curriculum is divided into six scientific areas, each area containing a set of courses (Table 7).

Details of each area, including course syllabus can be found elsewhere [5]. Three editions of MSc have been conducted from 1997 to 2000, with excellent receptiveness (over 100 candidates per year).

\section{Conclusions}

The inquiry of the Polish industry revealed the need to develop several studies in management for construction professionals. The experience gained from other European countries is important in order to tailor these studies to the requirements of the free market.

The need to improve management skills of construction professionals has also been felt in Portugal. Moreover, Portuguese undergraduate programmes in civil engineering have a great focus in design, therefore leading graduates seek for complementary training in management topics in construction. The MSc in Construction and Real Estate Management of University of Minho has been a contribution to fulfil that demand.
Experiences on this issue have been shared between the two countries within the scope of a Leonardo da Vinci project conducted from 1998 to 2001 that also gained insights into the reality of other European Countries, especially in the British long tradition in the subject. The project was entitled Development of New Type of Studies and Courses in the Field of Management for Engineers According to the Requirements of European Union. The main goal of the project was to improve the education system of construction staff in Poland, gaining from insights into the reality of other European Countries (especially Britain), and benefiting from the Portuguese experience reported above.

\section{References}

1. Minasowicz, A.; Teixeira, J. Construction Project Management Studies in Poland and in Portugal. Second SENET Conference on Project Management. Cavtat, Croatia, 17-20 April 2002.

2. Teixeira, J. Construction Site Impacts in Civil Engineering Education. Environmental Aspects in Civil Engineering Education. Fourth AECEF International Symposium. Porto, September 2002.

3. Development of New Management Studies and Courses in the Field of Management in Construction for Engineers According to the Requirements of European Union (2002). Product 1: Results of the Questionnaire among Construction Engineers and Managers Regarding Actual Educational Needs and Raising of Managerial Skills. 
4. Development of New Management Studies and Courses in the Field of Management in Construction for Engineers According to the Requirements of European Union (2002). Product 2: Structure of Knowledge for the Faculty of Construction Engineering and Management.
5. Development of New Management Studies and Courses in the Field of Management in Construction for Engineers According to the Requirements of European Union (2002). Product 3: Report on Portuguese survey.

\section{STATYBOS VADYBOS MOKYMAS LENKIJOJE IR PORTUGALIJOJE}

\section{K. Cieszyński, A. Minasowicz, P. O. Nowak, J. C. Teixeira}

\section{S antrauka}

Buvusios centralizuotos ekonomikos šalys šiuo metu susiduria su problema - kaip pritaikyti savo gamybos struktūras rinkos ekonomikai. Per paskutinius dvylika metų Lenkija šioje srityje padare didelę pažangą didindama investicijas i statybą ir tūkstančius naujai besikuriančių smulkiujų ir vidutinių statybos imonių. Tačiau tų Ł̇monių personalas ne visai atitinka šiuolaikinius reikalavimus dèl vadybos žinių stokos. Portugalijoje rinkos ekonomikos santykiai vystėsi nenutrūkstamai, tačiau dauguma statybos inžinerijos studiju programų nepajëgia užtikrinti jaunų statybos specialistų reikiamo žiniu lygio. Taigi nauji reikalavimai, keliami statybos pramonės projektų vadybos žinioms, skatina abiejų šalių aukštojo mokslo institucijas patenkinti ši poreiki. Šiame straipsnyje aprašomi LEONARDO DA VINCI projekto metu atlikto tyrimo tikslai ir išvados, susiję su Lenkijos statybos specialistų rengimo sistema ir jiems teikiamu techninių bei vadybos žinių kokybe.

Raktažodžiai: vadyba, mokymas, statyba, Lenkija, Portugalija.

Kazimierz CIESZYŃSKI. Professor, Department of Construction Engineering and Management, Civil Engineering Faculty, Warsaw University of Technology.

First degree in civil engineering, Warsaw University of Technology (1952), Master of Science (1954), PhD. Eng. (1964), DSc. (1969), Professor (1979). Practices in connection with "TEMPUS" Project in German speaking countries (1991-1992), essential coordination in Leonardo da Vinci Project "Development of new type of studies and courses in the field of management in construction for engineers according to the requirements of European Union" (1999-2001), scientific consultant in Leonardo da Vinci Project "Model of professional qualification structure and new methods of promotion, certification and mutual recognition of managerial skills in construction industry according to EU requirements" (2002-2004), initiation of educational specialty "Management and engineering production in construction" at Higher School of International Commerce and Finance (since 2003).

Former Director of Construction Engineering and Management Department at Civil Engineering Faculty of Warsaw University of Technology, member of CIOB from 2005, round 200 scientific publications - in those 15 books, promoter of 11 doctors in technical science.

Research interests: construction technology and organisation, project management, management in construction.

Andrzej MINASOWICZ. PhD Eng., Lecturer in Department of Construction Engineering and Management, Civil Engineering Faculty, Warsaw University of Technology.

First degree in civil engineering, Warsaw University of Technology, Master of Science (1968), PhD (1976). Work on the project „Expert system for site's installation“ at University of Karlsruhe (1991), co-ordinator of the Leonardo da Vinci Project "Development of new type of studies and courses in the field of management in construction for engineers according to the requirements of european union" (1999-2001), co-ordinator of the Leonardo da Vinci Project "Improvement of the linguistic skills of polish and portuguese construction managers and engineers - recognition of needs and preparation of courses in construction english language" (2001-2004), co-ordinator of the Leonardo da Vinci Project: "Model of professional qualifications structure and new methods of promotion, certification and mutual recognition of managerial skills in construction industry according to the requirements of EU" (2002-2004).

Vice Director of Construction Engineering and Management Department at Civil Engineering Faculty of Warsaw University of Technology, President of Polish British Construction Partnership Sp. z o.o., Fellow of The Chartered Institute of Building (FCIOB) from 2005, Member of Association of Consulting Engineers and Experts (SIDIR), Fellow of Institution of Civil Engineering (ICE), Member of The Association for Total Cost Management, Member of American Association of Cost Estimators (AACE), Member of Science Association of Construction Process Engineering, President of Polish Association of Building Managers (2005)

Research interests: management in construction, risk management.

Paul Olaf NOWAK. PhD. Eng., lecturer, director of Polish British Construction Partnership.

Master of Science (1993) in civil engineering at Warsaw University of Technology, PhD. Eng. (2002). Training of Project Management in the TEMPUS program, on the Loughborough University of Technology, training of "Project and Construction Management" on the Manchester University of Technology (1997), Member of research team in the Inco Copernicus program, titled "EAST CON 2000, The Modernization of the Construction Industry in Russia and Poland: Policy Conditions and Organizational initiatives for Successful Transition Towards a Market Economy" (1998-2000), member of research team in the Leonardo da Vinci program, titled "Development of New Types of Studies and Courses in the Field of Management in Construction for Engineers According to the Requirements of EU" (1999-2001), member of research team in the Leonardo da Vinci program, titled "Improvements of the linguistic skills of Polish and Portuguese construction managers and engineers - recognition of needs and preparation of courses in Construction English Language" (2001-2004), member of research team in the Leonardo da Vinci program, titled "Model of Professional Qualifications Structure and 
New Methods of Promotion, Certification and Mutual recognition of Managerial Skills in Construction Industry According to the Requirements of EU" (2002-2004)

Vice President of Polish British Construction Partnership, Sp. z o.o., Fellow of The Chartered Institute of Building (FCIOB) from 2005, Member of Association of Consulting Engineers and Experts (SIDIR), member of Polish Association of Building Managers (2005).

Research interests: management in construction, international contracts conditions, public tender and building law.

José Manuel Cardoso TEIXEIRA. Graduation in Civil Engineering by Faculdade de Engenharia do Porto, in 1981, with final classification of 16. MSc in Building Construction by Faculdade de Engenharia da Universidade do Porto in October 1988 with final classification of MB. PhD in Construction Management by Loughborough University of Technology (United Kingdom) in October 1994.

Lecturing at Universidade do Minho since May 1982 in Civil Engineering Course. Assistant Trainee from 1 July 1985 to 3 November 1988. Assistant from 4 November 1988 to 3 December 1994. Auxiliary Professor from 4 December 1994 to 12 July 2000. Associate Professor from 13 July 2001. He has been responsible for several courses in the field of Management and Technology of Construction of the five year undergraduate programme at the University of Minho. He has also been responsible for several courses of MSc programmes in Municipal Engineering, Civil Engineering, Construction and Real Estate Management and Human Engineering at the

University of Minho. He has also lectured several professional courses at various institutions. He has been supervisor of final projects of undergraduates and several MSc and $\mathrm{PhD}$ dissertations.

Research interests: construction technology, construction project management, safety and environment in construction, sustainability. 